\title{
Evidence for rare crop weeds of the Caucalidion group in Southwestern Germany since the Bronze Age: palaeoecological implications
}

\author{
Dedicated to the memory of Gerhard Lang (1924-2016)
}

\author{
Manfred Rösch ${ }^{1}$ \\ Received: 9 August 2016 / Accepted: 14 May 2017 / Published online: 24 May 2017 \\ (c) The Author(s) 2017. This article is an open access publication
}

\begin{abstract}
The crop weed communities of dry calcareous soils are today very rare and endangered. In the first half of the 20th century this group was already in an advanced stage of disappearance, caused by the intensification of agriculture since the 19th century. Therefore, botanists only found these plants in a few regions with calcareous soils, obviously reflecting the geological conditions. But many archaeobotanical finds are in places where this species was never observed as a living plant and edaphic conditions seem to exclude it. In the western Lake Constance region floristic observations are lacking. Of Orlaya grandiflora, there is now proof from several pollen diagrams that this species did occur regularly and with high frequency in this region from the Late Bronze Age to the 19th century AD. Several other species of the Caucalidion are also reflected in the pollen record, but are less frequent, reflecting the ecological conditions triggered by agriculture; due to soil erosion, topsoils were thin, especially on slopes, with low water capacity, and low yields. The weeds with spiny fruits were distributed over long distances by migrating domestic animals. Pollen grains in high-resolution pollen profiles from the northern Black Forest and Allgäu, where these plants were not to be expected and were never observed, indicate a ubiquitous distribution of the Caucalidion between Late Bronze Age and early Modern Ages in Central Europe and adjacent regions, reflecting the tenuous situation of long-term extensive ard agriculture in hilly landscapes. More and better pollen diagrams and macrofossil studies would bring better evidence.
\end{abstract}

Keywords Crop weeds $\cdot$ Macrofossil evidence $\cdot$ Pollen evidence $\cdot$ Agriculture $\cdot$ Human impact

\section{Introduction}

Besides crops, their weeds also have attracted the interest of archaeobotanists and were regarded as a good proxy for evaluating agriculture and environment (Willerding 1986). Since early times Old World cereals were accompanied by very conspicuous weeds of many different colours. Only in the last two centuries, since the development of modern

Communicated by F. Bittmann.

Manfred Rösch

manfred.roesch@rps.bwl.de

Regierungspräsidium Stuttgart, Landesamt für Denkmalpflege, Fischersteig 9,

78343 Gaienhofen-Hemmenhofen, Germany agriculture, this picture has started to fade (Oberdorfer 1957, 1983). These weeds belong to the Mediterranean and Middle East (Irano-Turanic) floral element of the steppe and dry grassland and came as archaeophytes into temperate Europe, when agriculture and deforestation began. In a phytosociological classification by Hüppe and Hofmeister (1990), the weed societies of winter crops were, according to soil alkalinity, grouped into the Aperion spica-venti (Tx. in Oberd. 1949) cohort on acid soils, and the Caucalidion platycarpi (Tx. 1950) cohort on basic soils. Indicator species of the latter group are Adonis aestivalis, Adonis flammea, Bunium bulbocastanum, Caucalis platycarpos, Conringia orientalis, Kickxia elatine and K. spuria, Lathyrus aphaca, Melandrium noctiflorum, Neslia paniculata, Orlaya grandiflora, Scandix pecten-veneris and Turgenia latifolia. Also typical are Ajuga chamaepitys, Anagallis foemina, Bupleurum rotundifolium, 
Table 1 Caucalidion species; phytosociological characteristic: $A$ character species of the Caucalido-Adonidetum flammeae, $D V$ differential species of the Caucalidion, $V$ character species of the Caucalidion, $O$ character species of the Papaveretalia rhoeadis; present occurrence/endangerment: 0 extinct, 1 threatened by extinction, 2 very endangered, 3 endangered, 4 infrequent and therefore potentially endangered, 5 needs protection; archaeological periods as in Fig. 1

\begin{tabular}{|c|c|c|c|c|c|c|c|c|c|c|c|c|c|c|}
\hline Species & 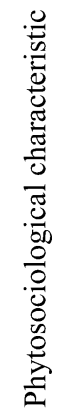 & 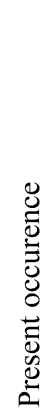 & 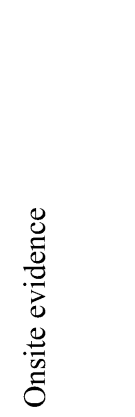 & 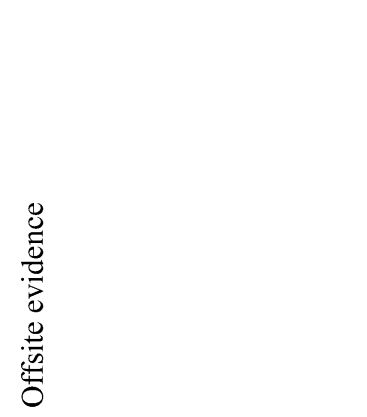 & : & ن己 & $\Xi$ & $\underset{\Sigma}{\Sigma}$ & $\underset{\Sigma}{Z}$ & $\sum_{0}^{3}$ & $\stackrel{\sim}{\stackrel{\sim}{I}}$ & $\stackrel{N}{\stackrel{D}{ }}$ & $\underset{3}{3}$ & $\stackrel{\mathscr{\sigma}}{\mathscr{b}}$ \\
\hline Adonis aestivalis & A & 3 & LB-MT & Adonis aestivalis-type & $\mathrm{x}$ & $\mathrm{x}$ & $\mathrm{x}$ & $\mathrm{x}$ & $\mathrm{x}$ & $\mathrm{x}$ & & & $\mathrm{x}$ & \\
\hline Adonis flammea & A & 1 & LB-HA & Adonis aestivalis-type & $\mathrm{x}$ & $\mathrm{x}$ & $\mathrm{x}$ & $\mathrm{x}$ & $\mathrm{x}$ & $\mathrm{x}$ & & & $\mathrm{x}$ & \\
\hline Ajuga chamaepitys & DV & 2 & LB-MT & Galeopsis-type & $\mathrm{x}$ & $\mathrm{x}$ & $\mathrm{x}$ & $\mathrm{x}$ & $\mathrm{x}$ & $\mathrm{x}$ & $\mathrm{x}$ & & $\mathrm{x}$ & $\mathrm{x}$ \\
\hline Anagallis foemina & $\mathrm{V}$ & 3 & YN-HM & Anagallis-type & & & & & & & & $\mathrm{x}$ & & \\
\hline Androsace maxima & $\mathrm{V}$ & 0 & - & - & & & & & & & & & & \\
\hline Asperula arvensis & $\mathrm{V}$ & 0 & EN-LM & Rubiaceae & $\mathrm{x}$ & $\mathrm{x}$ & $\mathrm{x}$ & $\mathrm{x}$ & $\mathrm{x}$ & $\mathrm{x}$ & $\mathrm{x}$ & $\mathrm{x}$ & $\mathrm{x}$ & $\mathrm{x}$ \\
\hline Avena fatua & $\mathrm{V}$ & & YN-MT & Avena-type & $\mathrm{x}$ & $\mathrm{x}$ & $\mathrm{x}$ & $\mathrm{x}$ & $\mathrm{x}$ & $\mathrm{x}$ & $\mathrm{x}$ & $\mathrm{x}$ & $\mathrm{x}$ & $\mathrm{x}$ \\
\hline Bifora radians & $\mathrm{V}$ & & - & - & & & & & & & & & & \\
\hline Bunium bulbocastanum & DV & 2 & EM & Peucedaum palustre-type & $\mathrm{x}$ & $\mathrm{x}$ & $\mathrm{x}$ & $\mathrm{x}$ & $\mathrm{x}$ & $\mathrm{x}$ & $\mathrm{x}$ & $\mathrm{x}$ & $\mathrm{x}$ & $\mathrm{x}$ \\
\hline Bupleurum rotundifolium & $\mathrm{V}$ & 1 & HA-MT & Bupleurum & $\mathrm{x}$ & $\mathrm{x}$ & $\mathrm{x}$ & $\mathrm{x}$ & $\mathrm{x}$ & $\mathrm{x}$ & $\mathrm{x}$ & $\mathrm{x}$ & $\mathrm{x}$ & \\
\hline Campanula rapunculoides & DV & & YN-HM & Campanula rapunculoides & & & $\mathrm{x}$ & $\mathrm{x}$ & & & & & & $\mathrm{x}$ \\
\hline Caucalis platycarpos & A & & LB-HM & Caucalis platycarpos & $\mathrm{x}$ & $\mathrm{x}$ & $\mathrm{x}$ & $\mathrm{x}$ & $\mathrm{x}$ & $\mathrm{x}$ & & $\mathrm{x}$ & $\mathrm{x}$ & \\
\hline Conringia orientalis & A & 2 & HA-LM & Brassicaceae & $\mathrm{x}$ & $\mathrm{x}$ & $\mathrm{x}$ & $\mathrm{x}$ & $\mathrm{x}$ & $\mathrm{x}$ & $\mathrm{x}$ & $\mathrm{x}$ & $\mathrm{x}$ & $\mathrm{x}$ \\
\hline Consolida regalis & $\mathrm{V}$ & 5 & YN-LM & Consolida-type & $\mathrm{x}$ & $\mathrm{x}$ & $\mathrm{x}$ & $\mathrm{x}$ & $\mathrm{x}$ & & & & & \\
\hline Euphorbia exigua & $\mathrm{V}$ & & MN-MT & Euphorbia & $\mathrm{x}$ & $\mathrm{x}$ & $\mathrm{x}$ & $\mathrm{x}$ & $\mathrm{x}$ & & & & $\mathrm{x}$ & $\mathrm{x}$ \\
\hline Euphorbia falcata & $\mathrm{V}$ & 0 & - & Euphorbia & $\mathrm{x}$ & $\mathrm{x}$ & $\mathrm{x}$ & $\mathrm{x}$ & $\mathrm{x}$ & & & & $\mathrm{x}$ & $\mathrm{x}$ \\
\hline Falcaria vulgaris & DV & 3 & SM & Falcaria vulgaris & $\mathrm{x}$ & $\mathrm{x}$ & $\mathrm{x}$ & $\mathrm{x}$ & $\mathrm{x}$ & $\mathrm{x}$ & $\mathrm{x}$ & $\mathrm{x}$ & $\mathrm{x}$ & $\mathrm{x}$ \\
\hline Fumaria vaillantii & DV & 5 & - & Fumaria & $\mathrm{x}$ & & $\mathrm{x}$ & & $\mathrm{x}$ & & & & & \\
\hline Galeopsis ladanum & DV & 3 & HA-MT & Galeopsis-type & $\mathrm{x}$ & $\mathrm{x}$ & $\mathrm{x}$ & $\mathrm{x}$ & $\mathrm{x}$ & $\mathrm{x}$ & $\mathrm{x}$ & $\mathrm{x}$ & $\mathrm{x}$ & $\mathrm{x}$ \\
\hline Galium tricornutum & DV & 2 & HA-MT & Rubiaceae & $\mathrm{x}$ & $\mathrm{x}$ & $\mathrm{x}$ & $\mathrm{x}$ & $\mathrm{x}$ & $\mathrm{x}$ & $\mathrm{x}$ & $\mathrm{x}$ & $\mathrm{x}$ & $\mathrm{x}$ \\
\hline Kickxia elatine & DV & & HM-MT & Kickxia & $\mathrm{x}$ & $\mathrm{x}$ & $\mathrm{x}$ & $\mathrm{x}$ & $\mathrm{x}$ & & $\mathrm{x}$ & $\mathrm{x}$ & $\mathrm{x}$ & $\mathrm{x}$ \\
\hline Kickxia spuria & DV & & LT-FM & Kickxia & $\mathrm{x}$ & $\mathrm{x}$ & $\mathrm{x}$ & $\mathrm{x}$ & $\mathrm{x}$ & & $\mathrm{x}$ & $\mathrm{x}$ & $\mathrm{x}$ & $\mathrm{x}$ \\
\hline Lathyrus tuberosus & $\mathrm{V}$ & & - & Lathyrus-type & $\mathrm{x}$ & $\mathrm{x}$ & $\mathrm{x}$ & & $\mathrm{x}$ & & $\mathrm{x}$ & & & $\mathrm{x}$ \\
\hline Legousia hybrida & $\mathrm{V}$ & 1 & MT & Legousia-type & $\mathrm{x}$ & $\mathrm{x}$ & $\mathrm{x}$ & $\mathrm{x}$ & $\mathrm{x}$ & & & & & \\
\hline Legousia speculum-veneris & $\mathrm{V}$ & 2 & RP-HM & Legousia-type & $\mathrm{x}$ & $\mathrm{x}$ & $\mathrm{x}$ & $\mathrm{x}$ & $\mathrm{x}$ & & & & & \\
\hline Melampyrum arvense & $\mathrm{V}$ & & YN-LM & Melampyrum & $\mathrm{x}$ & $\mathrm{x}$ & $\mathrm{x}$ & $\mathrm{x}$ & $\mathrm{x}$ & $\mathrm{x}$ & $\mathrm{x}$ & $\mathrm{x}$ & $\mathrm{x}$ & $\mathrm{x}$ \\
\hline Silene noctiflora & DV & & YN-SM & Melandrium-type & $\mathrm{x}$ & $\mathrm{x}$ & $\mathrm{x}$ & $\mathrm{x}$ & $\mathrm{x}$ & & $\mathrm{x}$ & $\mathrm{x}$ & $\mathrm{x}$ & $\mathrm{x}$ \\
\hline Myagrum perfoliatum & $\mathrm{V}$ & 1 & - & Brassicaceae & $\mathrm{x}$ & $\mathrm{x}$ & $\mathrm{x}$ & $\mathrm{x}$ & $\mathrm{x}$ & $\mathrm{x}$ & $\mathrm{x}$ & $\mathrm{x}$ & $\mathrm{x}$ & $\mathrm{x}$ \\
\hline Nigella arvensis & DV & 1 & RP & Nigella & & & $\mathrm{x}$ & & & & & & & $\mathrm{x}$ \\
\hline Nonea pulla & DV & 4 & - & - & & & & & & & & & & \\
\hline Orlaya grandiflora & $\mathrm{V}$ & 0 & LB-MT & Orlaya grandiflora & $\mathrm{x}$ & $\mathrm{x}$ & $\mathrm{x}$ & $\mathrm{x}$ & $\mathrm{x}$ & $\mathrm{x}$ & $\mathrm{x}$ & $\mathrm{x}$ & $\mathrm{x}$ & $\mathrm{x}$ \\
\hline Polycnemum arvense & DV & 0 & - & Polycnemum & $\mathrm{x}$ & & & & & & & & & \\
\hline Rapistrum rugosum & DV & 3 & - & Brassicaceae & $\mathrm{x}$ & $\mathrm{x}$ & $\mathrm{x}$ & $\mathrm{x}$ & $\mathrm{x}$ & $\mathrm{x}$ & $\mathrm{x}$ & $\mathrm{x}$ & $\mathrm{x}$ & $\mathrm{x}$ \\
\hline Sherardia arvensis & DV & & HA-LM & Rubiaceae & $\mathrm{x}$ & $\mathrm{x}$ & $\mathrm{x}$ & $\mathrm{x}$ & $\mathrm{x}$ & $\mathrm{x}$ & $\mathrm{x}$ & $\mathrm{x}$ & $\mathrm{x}$ & $\mathrm{x}$ \\
\hline Stachys annua & DV & 2 & YN-MT & Ballota-type & $\mathrm{x}$ & $\mathrm{x}$ & $\mathrm{x}$ & $\mathrm{x}$ & $\mathrm{x}$ & $\mathrm{x}$ & $\mathrm{x}$ & $\mathrm{x}$ & $\mathrm{x}$ & $\mathrm{x}$ \\
\hline Thymelaea passerina & DV & 1 & LB-SM & Thymelaea passerina & & & & $\mathrm{x}$ & & & & & & \\
\hline Torilis arvensis & $\mathrm{V}$ & 3 & LB-HM & Torilis arvensis & $\mathrm{x}$ & $\mathrm{x}$ & $\mathrm{x}$ & $\mathrm{x}$ & & & $\mathrm{x}$ & & & \\
\hline Turgenia latifolia & $\mathrm{A}$ & 0 & - & Turgenia latifolia & & & & & & & & $\mathrm{x}$ & & \\
\hline Vaccaria pyramidata & $\mathrm{V}$ & 1 & RP-MT & Vaccaria pyramidata & $\mathrm{x}$ & $\mathrm{x}$ & & $\mathrm{x}$ & & & & & & \\
\hline Valerianella rimosa & $\mathrm{O}$ & 3 & LN-MT & Valerianella & $\mathrm{x}$ & $\mathrm{x}$ & & $\mathrm{x}$ & & & $\mathrm{x}$ & & & $\mathrm{x}$ \\
\hline
\end{tabular}


Consolida regalis, Lathyrus tuberosus, Legousia speculumveneris, Sherardia arvensis, Stachys annua, Thymelaea passerina, Torilis arvensis and Valerianella rimosa, to name only the most important (Table 1). All these plants are today very rare in Central Europe, endangered and partly already extinct (Sebald et al. 1990-1998; Breunig and Demuth 1999; Oberdorfer 2001).

The Caucalido-Adonidetum flammeae occurs on dry, calcareous soils (Wilmanns 1993). Its typical members show therefore a rather patchy geographical distribution, which according to most vegetation scientists is caused by rockbed/ soil and climate. Many of them have not only beautiful flowers but also rather large and characteristic, often spiny, fruits or seeds and typical pollen grains as well. Therefore, their former distribution can be studied by archaeobotanical methods, giving evidence of former land use and cultural landscape.

A typical example is Orlaya grandiflora, which is, like other Caucalidion species, restricted to dry places with calcareous soils (Hegi 1975). In Central Europe, Orlaya grandiflora is more or less an obligate crop weed, whereas in other regions, for example in northern Italy, where it has been observed since the Early Bronze Age (EBA), it is today a plant of forest fringes and dry meadows (Perego et al. 2011).

One of the first discoveries of Orlaya grandiflora in south-west Germany was in the Roman Vicus of Welzheim (Körber-Grohne and Piening 1983). This was used as an argument for cereal importation into this site, because Orlaya grandiflora was never seen as a living plant in its vicinity (north-eastern quarter of topographic map 1:25,000, Welzheim, Sebald et al. 1990-1998). But a comparison of the crop weeds in Roman sites along the Upper GermanRhaetian Limes shows a clear correlation between their ecological indicator values and the local geological situation, and so indicates local crop production (Körber-Grohne and Rösch 1988; Rösch 1989). A later compilation of crop weed evidence in Baden-Württemberg resulted in more examples of its former occurrence where the plants have never been recorded by floristic documentation (Rösch 1998, 2008).

Archaeobotanical evidence of Caucalidion species for prehistoric periods is also given from Switzerland, Austria, the Balkans and the western Europe loess belt (Kroll and Borojevic 1988; Kreuz 2005; Bakels 2009; Jacomet and Brombacher 2009; Kohler-Schneider et al. 2015; Kroll and Reed 2016).

\section{Materials and methods}

Botanical on-site (mostly macrofossil) data from archaeological sites in Southwest Germany were evaluated, using the ARBODAT database (Kreuz and Schäfer 2002). In total 320 sites with more than 1,000 features were evaluated by calculating ubiquities for archaeological periods, based on archaeological sites. In the ubiquity calculation only onsite data are included, mostly macrofossils and a few pollen grains from vessel contents. The material is partly wet preserved, partly charred. On-site pollen evidence from vessel contents was included, but not desiccated macrofossils from buildings. With bee-transported pollen, long-distance transport from further away than $5 \mathrm{~km}$ can be excluded. The pollen spectra of the vessel contents indicate clearly locally or regionally produced honey. Long-distance transport by trade is not likely. Pollen evidence comes from profundal sediment cores of small lakes in the northern Black Forest (Nordschwarzwald), western Lake Constance (Bodensee) region and Allgäu, and from littoral cores of Lake Constance that were sampled continuously, most samples analysed with an arboreal sum of 1,000 . The whole data set consists of several thousand samples with several million pollen grains counted. The Oxcal time models are based on more than 200 radiocarbon dates (Ramsey and Lee 2013). The pollen type nomenclature follows Beug (2004). Off-site pollen and on-site macrofossil evidence complement each other, because they are from different locations, even from different regions. In contrast to macrofossils, pollen can be transported over bigger distances, which makes its interpretation in terms of local presence of plants, particularly those that are wind-pollinated, difficult (Behre and Kučan 1986). However, the crop weeds in consideration are not wind-pollinated so transport from distances of more than few kilometres is not very probable.

\section{Results}

Seven species of the Caucalidion, Torilis arvensis, Orlaya grandiflora, Adonis aestivalis and A. flammea, Caucalis platycarpos, Scandix pecten-veneris and Thymelaea passerina, mostly character species of the Caucalido-Adonidetum flammeae Tx. 50 are documented from the LBA and for all following periods (Fig. 1a, b). The ubiquity is highest in the Early Medieval (EM) and High Medieval (HM) periods, with the highest score of $38 \%$ for Orlaya grandiflora during HM2 (about AD 1150-1250).

From the Hallstatt period onwards, Neslia paniculata, Bupleurum rotundifolium and Galium tricornutum are present, with more or less continuous occurrence through all following periods (Fig. 1b).

From the Latène period onwards, but with lower ubiquity, Sherardia arvensis and Kickxia spuria occur, while from the Roman period onwards Vaccaria hispanica, Ranunculus arvensis, Legousia speculum-veneris, Ajuga chamaepitys, Galeopsis ladanum and Nigella arvensis are present (Fig. 1c, d). The latest to appear are Bunium bulbocastanum (Merovingian period), Conringia orientalis, Kickxia elatine (HM) 
Fig. 1 Ubiquity of Caucalidion species in south-west Germany for archaeological periods, based on archaeological features: a some early appearing species, b some later appearing species, c some late appearing species, d some very late appearing species; EN Early Neolithic, $M N$ Middle Neolithic, $Y N$ Younger Neolithic, $L N$ Late Neolithic, $E / M B$ Early/Middle Bronze Age, $L B$ Late Bronze Age, $H A$ Hallstatt period, $L T$ Latène period, $R P$ Roman period, $M P$ Migration period, EM1 Early Medieval 1 (Merovingian period), EM2 Early Medieval 2 (Carolingian and Ottonian period), HM1 High Medieval 1 (Salian period), HM2 High Medieval 2 (Staufian period), LM Late medieval, MT Modern Times

and Legousia hybrida (Modern times) (Fig. 1d). It is important to mention that Caucalidion crop weeds are absent in the Neolithic, with very few exceptions (single finds) for the Younger Neolithic, such as Stachys annua (Riedschachen, Bertsch 1931), Lithospermum arvense (Aulendorf, Steger See, Rösch 2013a), Silene noctiflora, (Hornstaad-Hörnle IB, Rösch 1985), Consolida regalis and Anagallis foemina (Aulendorf, Steger See, Rösch 2013a). These are regarded as weak Caucalidion members, if at all (Oberdorfer 2001).

Focusing on Orlaya grandiflora (Fig. 2), one of the members of the group best represented in the archaeobotanical record and today extinct as a crop weed in Baden-Württemberg (Sebald et al. 1990-1998), the mapping of the finds, differentiated in periods, in most cases does not coincide with the floristic record covering the last 200 years; most archaeobotanical finds are at places where the plant has never been observed (Fig. 3). Vice versa, archaeobotanical investigations are often lacking at places where the species has been documented floristically. The floristic mapping of Baden-Württemberg has about 350 grid squares, which were all surveyed evenly, whereas the 320 archaeobotanical data sets were not evenly distributed.

The archaeobotanical record is patchy in time and space. To make it at least continuous in time, pollen profiles can be helpful. They are continuous in time, but also patchy in space, because in Baden-Württemberg suitable pollen sites are restricted to the pre-Alpine lowlands and the Black Forest (Fig. 3). In these regions, Orlaya grandiflora could not be expected, and was never observed during the last two centuries, for geological, soil and climate reasons. The floristic records of Orlaya grandiflora are mostly from limestone, less so from loess regions (Sebald et al. 1990-1998).

Orlaya grandiflora has a rather easily recognizable pollen grain (Beug 2004), which is more common in the pollen record than most other crop weeds, with the exception of Centaurea cyanus. However, as an entomophilous species, pollinated by night butterflies and other hexapods (Hegi 1975), its presence in pollen profiles is still in the range of one per thousand or less. So it occurs normally only in the pollen record when the pollen sum is high. This is the case in the western Lake Constance region, were several diagrams were analysed continuously with
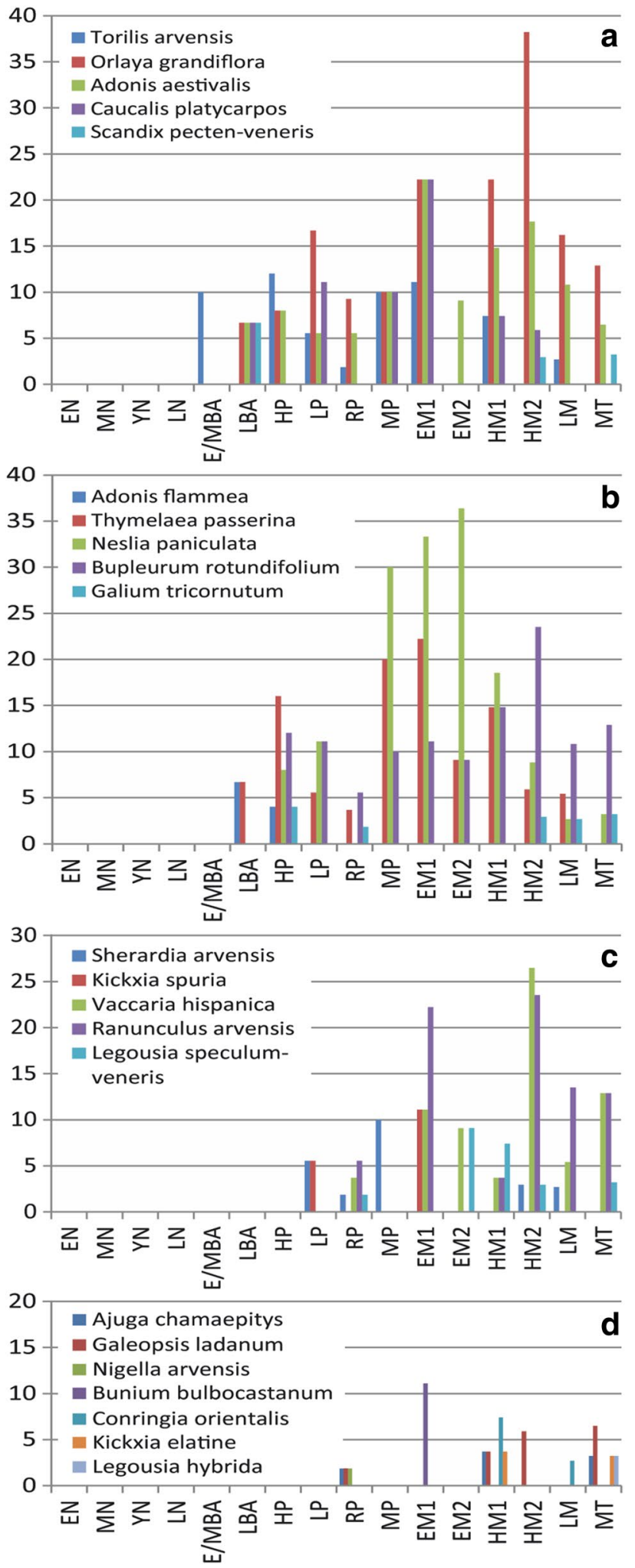

high pollen sums covering the last seven millennia (Rösch 1992, 1993, 2013b; Rösch et al. 2014a, b; Rösch and Lechterbeck 2016). 

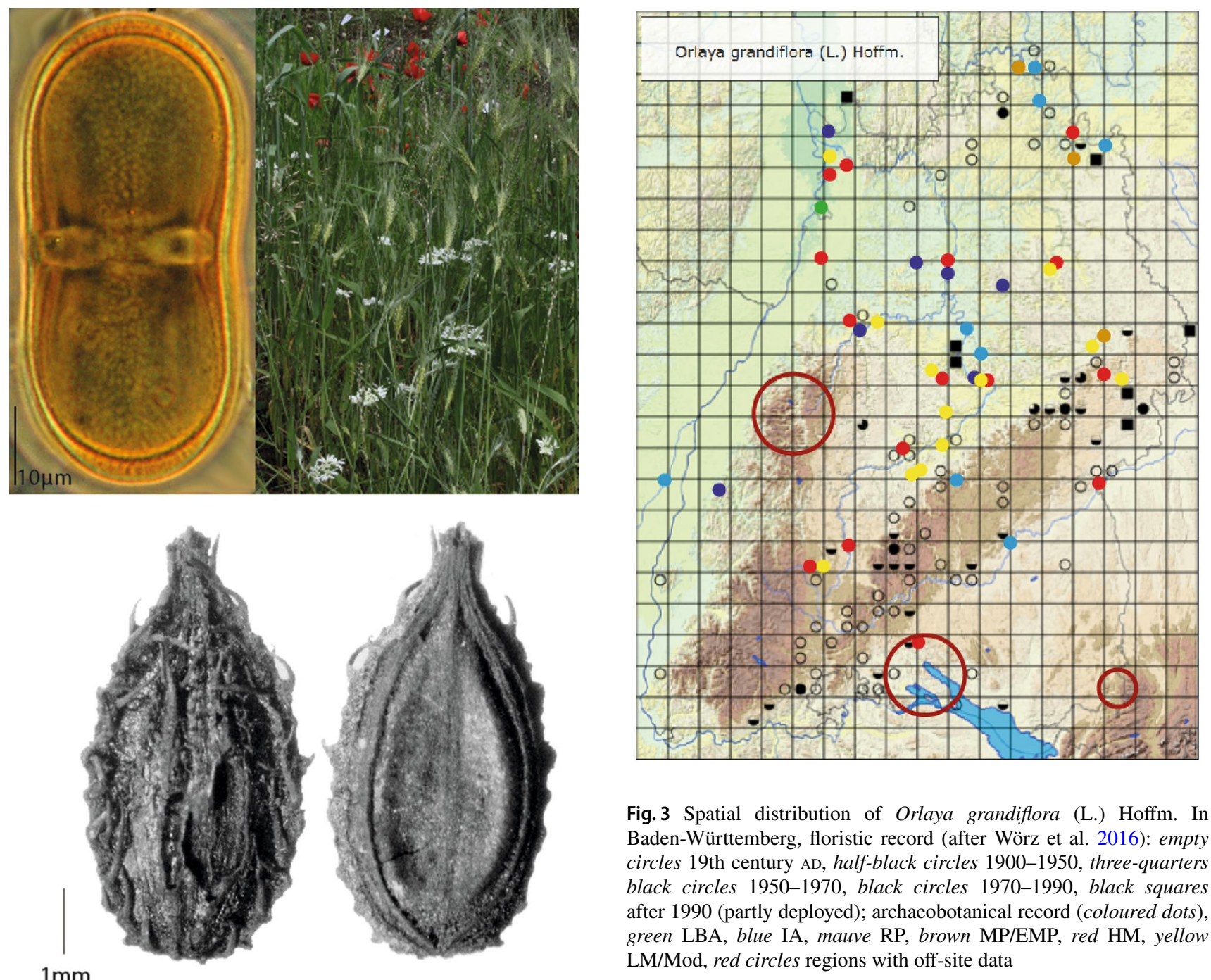

Fig. 3 Spatial distribution of Orlaya grandiflora (L.) Hoffm. In Baden-Württemberg, floristic record (after Wörz et al. 2016): empty circles 19th century AD, half-black circles 1900-1950, three-quarters black circles 1950-1970, black circles 1970-1990, black squares after 1990 (partly deployed); archaeobotanical record (coloured dots), green LBA, blue IA, mauve RP, brown MP/EMP, red HM, yellow $\mathrm{LM} / \mathrm{Mod}$, red circles regions with off-site data

Fig. 2 Orlaya grandiflora (L.) Hoffm.: Pollen, Mindelsee, medieval; Charred fruit, Geislingen, Late medieval; plant, archaeobotanical garden Hemmenhofen, summer 2016

The profiles indicate a more or less synchronous development of the cultural landscape (Fig. 4). Grasses and herbs greatly increase, especially in phases of strong human impact, from the EBA onwards, indicating permanent openness of the landscape caused by forest grazing and arable fields with extensive ard cultivation (Kalis et al. 2003). During the Neolithic there is no significant increase of NAP during human impact phases, but instead an increase of shrubs, which was explained by Rösch et al. (2014a) as due to slash-and-burn agriculture. In contrast, Jacomet et al. (2016) explain their Neolithic on-site evidence as indicating permanent fields and animal browsing in the forest, postulating a larger opening of the landscape step by step, with even the use of fire to create pastures and better hunting opportunities. However, they ignore the NAP values in

pollen profiles, as well as the fact that in a broad-leafed forest the trees must first be cut down and the wood must dry before it is combustible.

There are records of Orlaya grandiflora pollen in six profiles (Table 2; Fig. 5). In Hornstaad, where the pollen sum is only 500 (Rösch 1992), only two grains were found, one medieval and one from the Hallstatt period. In the other five profiles, between 21 and 59 grains were recorded, three Iron Age grains from Mainau and Buchensee, two Roman period grains from Buchensee and Litzelsee, and many younger grains, covering the period from 6th to 19th century AD. During the vegetation studies of the 20th century in the western lake Constance region, neither the Caucalido-Adonidetum society nor any of its members could be observed, but only the Melandrietum noctiflori and the Kickxietum, associations of the Caucalidion on less dry soils (Lang 1990).

The northern Black Forest has poor, acid, sandy soils and a wet climate, but even here, Orlaya grandiflora was found in five profiles with a total of 17 pollen grains (Table 2; Fig. 5; Rösch 2009; Rösch and Tserendorj 


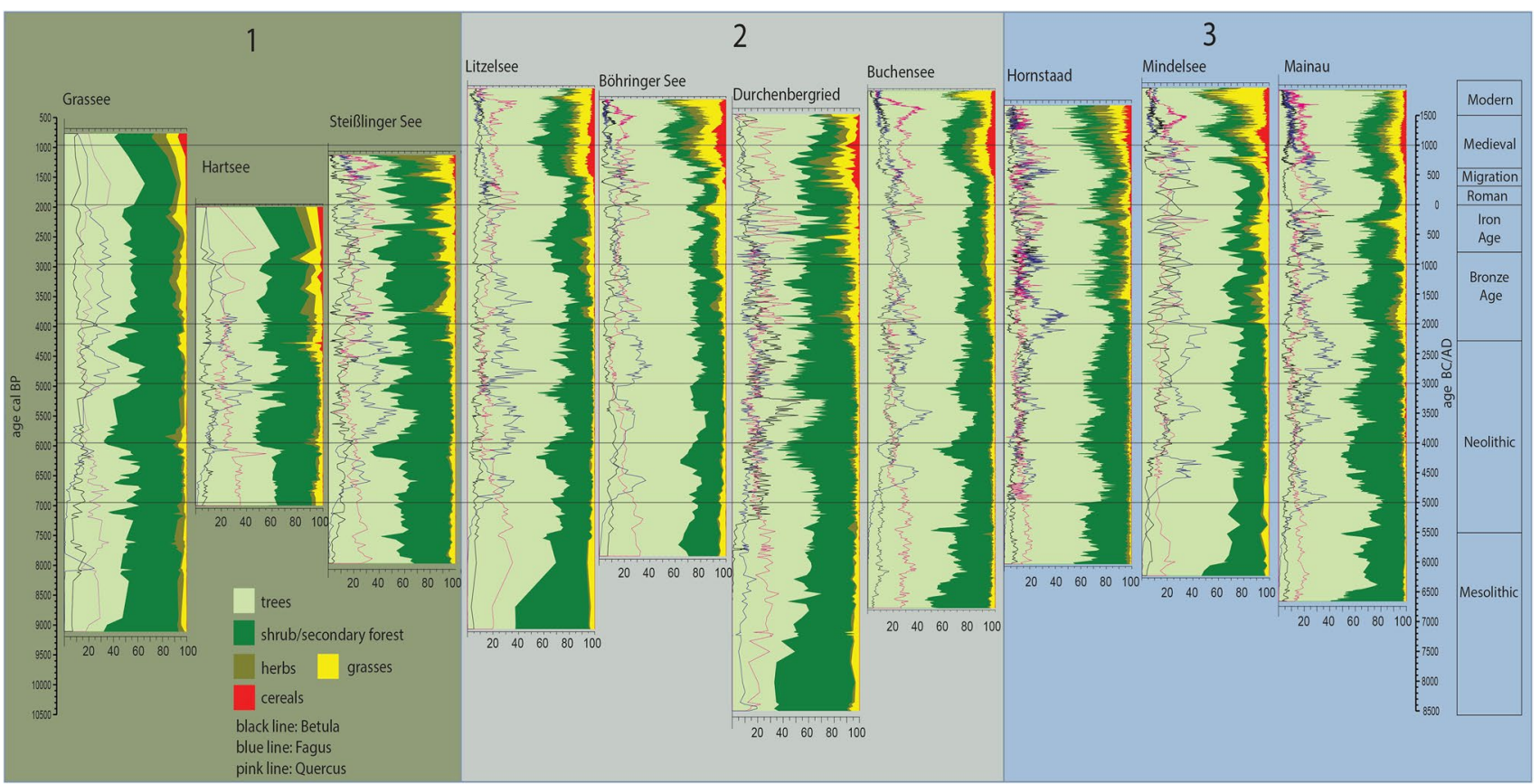

Fig. 4 Pollen profiles in the western Lake Constance region. Main diagrams on the same time scale; regions: 1 Hegau, 2 Lake Constance hinterland, 3 Lake Constance

Table 2 Orlaya grandiflora pollen grains in south-west German pollen profiles

\begin{tabular}{lccl}
\hline Site & Samples $(n)$ & Orlaya grains & $\begin{array}{l}\text { Orlaya } \\
\text { (ubiquity, } \\
\%)\end{array}$ \\
\hline \multicolumn{2}{l}{ Western Lake Constance area } & & \\
Böhringer See & 525 & 43 & 8.2 \\
Buchensee & 797 & 59 & 7.4 \\
Hornstaad & 862 & 2 & 0.2 \\
Litzelsee & 449 & 33 & 7.3 \\
Mainau & 985 & 44 & 4.5 \\
Mindelsee & 402 & 21 & 5.2 \\
Northern Black Forest & & & \\
Ellbachsee & 85 & 2 & 2.4 \\
Glaswaldsee & 153 & 2 & 1.3 \\
Herrenwieser See & 369 & 3 & 0.8 \\
Huzenbacher See & 364 & 3 & 0.8 \\
Wilder See & 259 & 8 & 3.1 \\
Allgäu & & & 1.9 \\
Großer Ursee & 895 & 17 & \\
\hline
\end{tabular}

2011). In this region, the archaeobotanical record is very sparse, because almost no excavations have taken place and Orlaya grandiflora was never observed as a plant, the same as with other species of the Caucalidion.

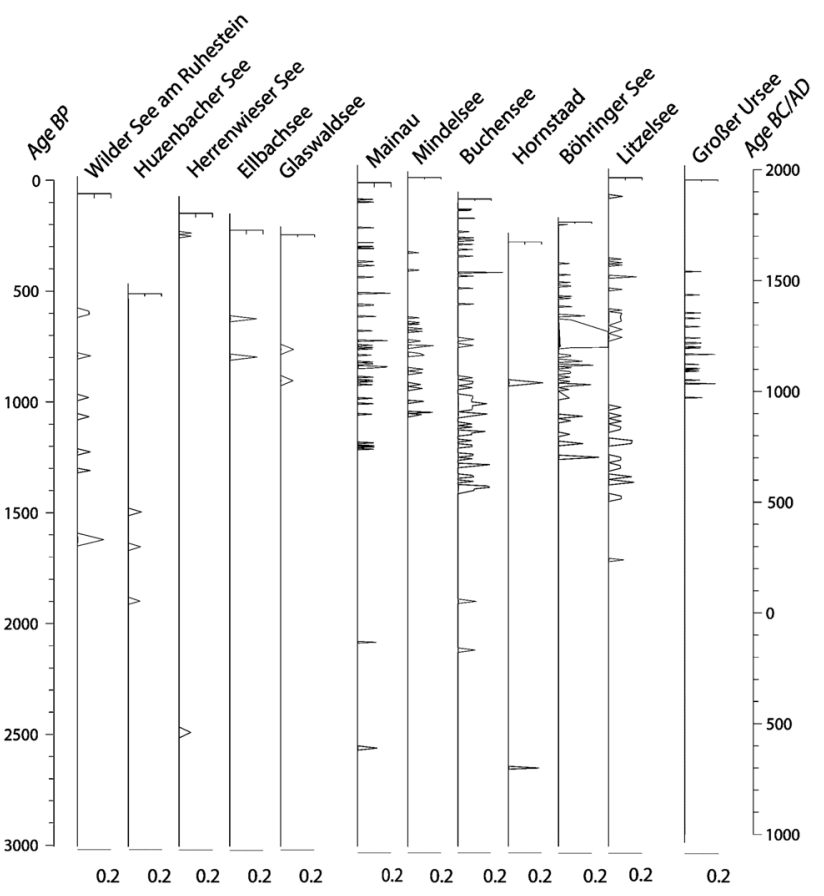

Fig. 5 Orlaya grandiflora (L.) Hoffm. Percentages in the pollen record of the northern Black Forest (Wilder See am Ruhestein to Glaswaldsee), western Lake Constance (Mainau to Litzelsee), and Allgäu region (Großer Ursee) 
The situation in Allgäu is similar regarding archaeobotanical and archaeological studies as well as floristic records. Nevertheless, in the pollen profile from Großer Ursee near Isny, 17 pollen grains of Orlaya grandiflora were detected, dating from the 10th to the 16th century AD (Table 2; Fig. 5; Rösch and Hahn 2016).

Putting the Orlaya grandiflora record in the broader context of the association (Table 1), on-site evidence of $30 \mathrm{Cau}-$ calidion species can be noted. In the off-site record even 36 taxa are possible, whereof only 12 are certain because many pollen types can only be identified on genus or family level. There is proof for perhaps both Adonis species, as well as for Bupleurum rotundifolium, Caucalis platycarpos, perhaps both Kickxia species, perhaps both Legousia species, Nigella arvensis, Polycnemum arvense, Thymelaea passerina, Torilis arvensis and Vaccaria pyramidata, to mention the most important. Turgenia latifolia is only documented as a single pollen grain at Huzenbacher See. Androsace maxima, Bifora radians and Nonnea pulla are totally lacking in the archaeobotanical on-site as well as off-site record.

\section{Discussion}

According to our material it seems obvious that the Caucalidion weed cohort in southwest Germany was far more widespread than today, from the LBA onwards with its widest occurrence in the medieval period, and was not restricted to regions with calcareous bedrock and soils. It even occurred in regions with very acid, poor soils such as the northern Black Forest, if we exclude importation of its pollen grains together with cereal pollen from far away, a rather improbable assumption. Differences in its ubiquity between landscapes may be assumed, as the Orlaya grandiflora pollen record indicates.

The difference between the occurrences today of the Caucalidion cohort and its former distribution has ecological reasons. The members of this group are light-demanding, but weak competitors, even compared with other crop weeds. Perhaps they are not obligate crop weeds, if such exist at all, but benefit, as annuals and pioneers with mostly big diaspores, from the disturbance of soil and vegetation by agriculture. Thymelaea passerina as well as Ajuga chamaepitys and Polycnemum majus, for example still occur in the Tauber region, but mostly no longer as crop weeds, but on disturbed places in dry grassland (Philippi 1993). Their physiological growing range is most probably rather broad, but their optimum, as with most plants, would be deep, fertile, but open soils with good water supply. However, on such soils they cannot compete with most other annuals, not to mention perennials. So they were displaced to poorer soils, which are too dry or too poor in nutrients for other crop weeds. On acid soils they must compete with other weeds like Arnoseris minima or Scleranthus annuus that can tolerate these conditions better.

Dry soils can be rich in clay, were the water is partly not available for the plants, or rich in rock, gravel or sand, where the water stock is small and disappears fast. The water supply of a soil is to a high degree determined by its thickness. Even Loess can have too low a water storage for good plant growth, when the thickness of the topsoil is small. In contrast to the conclusions the vegetation scientists draw from their observations covering the last two centuries, the basicity of the soil seems to play a minor role in the occurrence of these plants in the past.

After several millennia of soil development under woodland during the Late Weichselian and early Holocene, most topsoils were rather thick with a large water and nutrient stock and were very suitable for agriculture. There was no space for weak competitors. During three millennia of Neolithic agriculture this changed little, because Neolithic agriculture practices did not lead to soil erosion, at least not to a high degree (Leopold and Völkel 2007; Vogt 2014).

This changed from the Bronze Age onwards, when extensive ard cultivation led to strong soil erosion, at least on slopes and hilltops in hilly landscapes. This erosion process can be traced by colluvia and fillings of valleys (Bork et al. 1999). As a consequence, on slopes the soils became very shallow, with a low water storage capacity. Here and now, the Caucalidion species, protected by the dryness of the soil against stronger competitors, could develop well. On such fields, in normal years the yield was low, in dry years there was perhaps no yield at all. Attached to the fleeces of migrating flocks the weeds could easily invade other landscapes and also other vegetation than fields, for example fringes or overgrazed pastures, as long as disturbance created bare ground (Fischer et al. 1996; Römermann et al. 2005). There may have been slight changes in agriculture and especially land use pressure between Bronze Age and modern times, but the principles, a nutrient redistribution system with extensive ard cultivation and short fallow phases, remained the same (Menke 1995).

The situation changed slowly from the 18th century onwards: poor soils were either improved by stronger manuring and deep ploughing, or the fields were abandoned and converted into grassland (Achilles 1993). The terracing of fields on slopes prevented further soil erosion. The use of artificial fertilizer and herbicide since the 20th century accelerated the disappearance of these weeds. The disappearance was slower in limestone regions where soils are naturally dryer, and where they had been more common before. Here the botanists of the 19th and 20th centuries could still observe them. Today this group contains the most endangered plants in Europe. To allow them to survive, simple methods of nature conservation are not sufficient, because the plants need farming and soil disturbance by the 
plough, especially by a farmer using old-fashioned methods. Thus, nature conservation organizations must make contracts with farmers who still have fields with some of these species, to require them to work as their ancestors did (Rodi 1986; Meyer et al. 2013). Another method is to establish oldfashioned agriculture in open-air museums. For example, in the open-air museum Bad Windsheim (Frankonia) rare and endangered crop weeds have been promoted for the last 26 years by practicing old-fashioned agriculture (three-fieldsystems, Bärnthol, written communication, 25 July 2016).

\section{Conclusions}

According to archaeobotanical on-site and off-site evidence, the crop weeds of dry basic soils (Caucalidion cohort and particularly Caucalido-Adonidetum flammeae association) were much more common in southern Central Europe during the medieval period, and even earlier, than the floristic observations of the last two centuries suggest, occurring even in landscapes with poor acid soils. Their expansion started in the Bronze Age. The main reason is most probably the development of shallow topsoils on slopes and hilltops through soil erosion because of extensive ard cultivation, creating soil situations where these weak competitors could compensate for this weakness by their resistance to drought stress. A time gap in their expansion from the south to the north is perhaps caused by less steep landforms towards the north (Meurers-Balke et al. 2013). The application of marl to the fields since the Roman period may also have promoted their expansion, as stressed by Kreuz (2005). The yields to be expected on these shallow soils are low and endangered in dry years. The more or less complete lack of these species during the Neolithic contradicts the recently published opinion of Jacomet et al. (2016) of extensive ard cultivation already occurring in the Neolithic. Although a later arrival of all these species cannot be totally excluded, it is rather improbable.

A restriction of agriculture to totally flat landscapes during the Neolithic is rather improbable. The almost total lack of evidence for Neolithic soil erosion is not caused by the situation of the fields in the landscape but by their management. Hydrology is not only determined by the soil, but also by the climate. Many crop weeds of the Violenea arvensis were found in archaeological contexts earlier and were more frequently observed in eastern than in western Central Europe, for example Agrostemma githago and Centaurea cyanus (Willerding 1986). The reason is the dryer, sub-continental climate, which favours agriculture and crop weeds more than woodland and forest plants. Other weeds like Lapsana communis do not show these distribution patterns, but are more common in western Central Europe. In spite of their occurrence on fields, especially in the past, they cannot be regarded as crop weeds in a geobotanical sense, but as plants of forest and forest disturbances. The east-west gradient in forest density caused by the climate played an important role in the early stages of agriculture in Central Europe (Kunes et al. 2015).

In general, for the better understanding of the past, different proxies must be considered, for example on-site and off-site data, pollen and macrofossils. Pollen diagrams must be better worked out as is normally the case when dealing mainly with climate. Palaeoecological studies always need comparisons between different times and different regions: To understand the medieval, the present must be known. To understand the Bronze Age the medieval must be known. And to understand the Neolithic, the Bronze Age must be known. Furthermore, to understand land use in Northern Europe, land use in central Europe must be known, and European land use can only be understood knowing the situation in the Near East. Viewing only one period, focusing on a single site, as is often the case in archaeology and on-site archaeobotany, does not really help.

Acknowledgements For this paper partly unpublished data of Elske Fischer, Lucia Wick, and Marion Sillmann were used. Elske Fischer and the Forchtenberg group discussed the contents, Tanja Märkle designed or improved the figures. The research on which this paper is based was supported by the DFG during several projects.

Open Access This article is distributed under the terms of the Creative Commons Attribution 4.0 International License (http://creativecommons.org/licenses/by/4.0/), which permits unrestricted use, distribution, and reproduction in any medium, provided you give appropriate credit to the original author(s) and the source, provide a link to the Creative Commons license, and indicate if changes were made.

\section{References}

Achilles W (1993) Deutsche Agrargeschichte im Zeitalter der Reformen und der Industrialisierung. Ulmer, Stuttgart

Bakels CC (2009) The Western European loess belt. Agrarian history, 5300 BC-AD 1000. Springer, Dordrecht

Behre K-E, Kučan D (1986) Die Reflektion archäologisch bekannter Siedlungen in Pollendiagrammen verschiedener Entfernung: Beispiele aus der Siedlungskammer Flögeln, Nordwestdeutschland. In: Behre K-E (ed) Anthropogenic indicators in pollen diagrams. Balkema, Rotterdam, pp 95-114

Bertsch K (1931) Paläobotanische Monographie des Federseeriedes. Bibliotheca Botanica 103. Schweizerbart, Stuttgart

Beug HJ (2004) Leitfaden der Pollenbestimmung für Mitteleuropa und angrenzende Gebiete. Pfeil, München

Bork HR, Dalchow C, Frielinghaus M (1999) Bodenentwicklung, Bodenzerstörung und Schutzbedürftigkeit von Böden in der Vergangenheit. In: Frielinghaus M, Bork HR (eds) Schutz des Bodens. Umweltschutz-Grundlagen und Praxis 4. Economica, Bonn, pp 16-28

Breunig D, Demuth S (1999) Rote Liste der Farn-und Samenpflanzen Baden-Württembergs. Naturschutz-Praxis, Artenschutz 2. Landesanstalt für Umweltschutz Baden-Württemberg, Karlsruhe 
Fischer SF, Poschlod P, Beinlich B (1996) Experimental studies on the dispersal of plants and animals on sheep in calcareous grasslands. J Appl Ecol 33:1,206-1,222

Hegi G (1975) Illustrierte Flora von Mitteleuropa. 2nd edn. Parey, Berlin

Hüppe J, Hofmeister H (1990) Syntaxonomische Fassung und Übersicht über die Ackerunkrautgesellschaften der Bundesrepublik Deutschland. Ber Reinhold-Tüxen-Ges 2:61-81

Jacomet S, Brombacher C (2009) Geschichte der Flora in der Regio Basiliensis seit 7500 Jahren: Ergebnisse von Untersuchungen pflanzlicher Makroreste aus archäologischen Ausgrabungen. Mitteilungen der Naturforschenden Gesellschaften beider Basel 11:27-106

Jacomet S, Ebersbach R, Akeret Ö et al. (2016) On-site data cast doubts on the hypothesis of shifting cultivation in the late Neolithic (c. 4300-2400 cal. BC): Landscape management as an alternative paradigm. Holocene 26:1,858-1,874

Kalis AJ, Merkt J, Wunderlich J (2003) Environmental changes during the Holocene climatic optimum in central Europe: human impact natural causes. Quat Sci Rev 22:33-79

Kohler-Schneider M, Caneppele A, Heiss AG (2015) Land use, economy and cult in late Iron Age ritual centres: an archaeobotanical study of the La Tène site at Sandberg-Roseldorf. Veget Hist Archaeobot 24:517-540

Körber-Grohne U, Piening U (1983) Die Pflanzenreste aus dem Ostkastell von Welzheim mit besonderer Berücksichtigung der Graslandpflanzen. In: Körber-Grohne U, Kokabi M, Piening U, Planck D (eds) Flora und Fauna im Ostkastell von Welzheim. Forsch Ber Vor- Frühgesch Bad-Württ 14. Theiss, Stuttgart, pp 17-149

Körber-Grohne U, Rösch M (1988) Römerzeitliche Brunnenfüllung im Vicus von Mainhardt, Kreis Schwäbisch Hall. Fundber BadWürtt 13:307-323

Kreuz A (2005) Landwirtschaft im Umbruch? Archäobotanische Untersuchungen zu den Jahrhunderten um Christi Geburt in Hessen und Mainfranken. Ber RGK 85:97-292

Kreuz A, Schäfer E (2002) A new archaeobotanical database program. Veget Hist Archaeobot 11:177-180

Kroll H, Borojević K (1988) Einkorn von Feudvar, Vojvodina, Jugoslawien. Ein früher Beleg der Caucalidion-Getreideunkrautgesellschaft. Praehist Z 63:135-139

Kroll H, Reed K (2016) Die Archäobotanik. Feudvar III. Würzburger Studien zur Vor- und Frühgeschichtlichen Archäologie 1. Würzburg University Press, Würzburg

Kuneš P, Svobodová-Svitavská H, Kolář J, Hajnalová M, Abraham V, Macek M, Tkač, P, Szabó P (2015) The origin of grasslands in the temperate forest zone of east-central Europe: long-term legacy of climate and human impact. Quat Sci Rev 116:15-27

Lang G (1990) Die Vegetation des westlichen Bodenseegebietes, 2nd edn. Fischer, Stuttgart

Leopold M, Völkel J (2007) Colluvium: definition, differentiation and their possible suitability to reconstruct Holocene climate data. Quat Int 162-163:133-140

Menke B (1995) Vegetations- und Bodenentwicklung im Bereich der celtic fields im Gehege Ausselbek bei Ülsby, Kreis SchleswigFlensburg. Offa 52:7-28

Meurers-Balke J, Kalis AJ, Gerlach R (2013) Ein merowingerzeitlicher Prospektionsschacht in Rheinbach, Kr. Euskirchen. Archäobotanische und geoarchäologische Untersuchungen. In: Von Carnap-Bornheim C (ed) Von Sylt bis Kastanas. Offa 69/70. Wachholtz, Neumünster, pp 319-354

Meyer S, Hilbig W, Steffen K, Schuch S (2013) Ackerwildkrautschutz-Eine Bibliographie. BfN-Skripten 351. Bundesamt für Naturschutz, Bonn

Oberdorfer E (1957) Süddeutsche Pflanzengesellschaften. Fischer, Jena
Oberdorfer E (1983) Süddeutsche Pflanzengesellschaften, Teil III, 2nd edn. Fischer, Jena

Oberdorfer E (2001) Pflanzensoziologische Exkursionsflora für Deutschland und angrenzende Gebiete, 8th edn. Ulmer, Stuttgart

Perego R, Badino F, Deaddis M, Ravazzi C, Vallè F, Zanon M (2011) L'origine del paesaggio agro-pastorale in nord Italia: espansione di Orlaya grandiflora (L.) Hoffm. nella civiltàpalafitticola dell'età del Bronzo della regione del Garda. Notizie Archeol Bergomensi 19:161-173

Philippi G (1993) Thymelaea passerina im Taubergebiet. Carolinea $51: 108-111$

Ramsey CB, Lee S (2013) Recent and planned developments of the program OxCal. Radiocarbon 55:720-730

Rodi D (1986) Modelle zur Einrichtung und Erhaltung von FeldfloraReservaten in Württemberg. Verh Ges Ökol 14:167-172

Römermann C, Tackenberg O, Poschlod P (2005) How to predict attachment potential of seeds to sheep and cattle coat from simple morphological seed traits. OIKOS 110:219-230

Rösch M (1985) Die Pflanzenreste der neolithischen Ufersiedlung von Hornstaad-Hörnle I am westlichen Bodensee, 1. Bericht. In: Becker B, Billamboz A, Dieckmann B, Kokabi M, Kromer B, Liese-Kleiber H, Rösch M, Schlichtherle H, Strahm C (eds) Berichte zu Ufer- und Moorsiedlungen Südwestdeutschlands 2. Materialh Vor-Frühgesch Bad-Württ 7. Theiss, Stuttgart, pp 164-199

Rösch M (1989) Botanische Funde aus römischen Brunnen in Murrhardt, Rems-Murr-Kreis. Archäol Ausgr Bad-Württ 1988:114-118

Rösch M (1992) Human impact as registered in the pollen record: some results from the western Lake Constance region, Southern Germany. Veget Hist Archaeobot 1:101-109

Rösch M (1993) Prehistoric land use as recorded in a lake-shore core at Lake Constance. Veget Hist Archaeobot 2:213-232

Rösch M (1998) The history of crop and crop weeds in south-western Germany from the Neolithic period to modern times, as shown by archaeobotanical evidence. Veget Hist Archaeobot 7:109-125

Rösch M (2008) New aspects of agriculture and diet of the early medieval period in central Europe: waterlogged plant material from sites in south-western Germany. Veget Hist Archaeobot 17:225-238

Rösch M (2009) Zur vorgeschichtlichen Besiedlung und Landnutzung im nördlichen Schwarzwald aufgrund vegetationsgeschichtlicher Untersuchungen in zwei Karseen. Mitt Ver Forstl Standortskunde Forstpflanzenzüchtung 46:69-82

Rösch M (2013a) Pflanzliche Großreste aus Schichten der Schussenrieder und Pfyn-Altheimer Kultur aus dem Steeger See, Stadt Aulendorf, Landkreis Ravensburg. Fundber Bad-Württ 33:7-35

Rösch M (2013b) Change of land use during the last two millennia as indicated in the pollen record of a profundal core from Mindelsee, Lake Constance Region, Southwest Germany. In: Von CarnapBornheim C (ed) Von Sylt bis Kastanas. Offa 69/70, Wachholtz, Neumünster, pp 355-370

Rösch M, Hahn S (2016) Besiedlung und Landnutzung im Allgäu von der Jungsteinzeit bis zur Neuzeit-ein interdisziplinäres Forschungsprojekt. Arch Ausgr Bad-Württ 2015:45-50

Rösch M, Lechterbeck J (2016) Seven millennia of human impact as reflected in a high resolution pollen profile from the profundal sediments of Litzelsee, Lake Constance region, Germany. Veget Hist Archaeobot 25:339-358

Rösch M, Tserendorj G (2011) Florengeschichtliche Beobachtungen im Nordschwarzwald (Südwestdeutschland). Hercynia NF 44:53-71

Rösch M, Kleinmann A, Lechterbeck J, Wick L (2014a) Botanical offsite and on-site data as indicators of different land use systems: a discussion with examples from Southwest Germany. In: Bittmann F, Gerlach R, Rösch M, Schier W (eds) Farming in the forestecology and economy of fire in prehistoric agriculture. Veget Hist Archaeobot 23(Suppl 1):121-133 
Rösch M, Kleinmann A, Lechterbeck J, Wick L (2014b) Erratum to: Botanical off-site and on-site data as indicators of different land use systems: a discussion with examples from Southwest Germany. Veget Hist Archaeobot 23:647-648

Sebald O, Seybold S, Philippi G, Wörz A (1990-1998) Die Farn-und Blütenpflanzen Baden-Württembergs. Ulmer, Stuttgart

Vogt R (2014) Kolluvien als Archive für anthropogen ausgelöste Landschaftsveränderungen an Beispielen aus dem westlichen Bodenseegebiet. Materialhefte zur Archäologie in Baden-Württemberg 99. Theiss, Darmstadt
Willerding U (1986) Zur Geschichte der Unkräuter Mitteleuropas. Wachholtz, Neumünster

Wilmanns O (1993) Ökologische Pflanzensoziologie, 5th edn. Quelle \& Meyer, Heidelberg

Wörz A, Hölzer A, Thiv M (2016) Aktuelle Verbreitungskarten der Farn-und Blütenpflanzen Baden-Württembergs. http://www.flora. naturkundemuseum-bw.de 